\title{
Pathogen isolation and antibiogram analysis in dairy cows with clinical mastitis in Adana region, Turkey
}

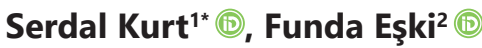 \\ ${ }^{1}$ Kahramanmaras Istiklal University, Elbistan Vocational School, Department of Veterinary, Kahramanmaras, Turkey \\ ${ }^{2}$ Cukurova University, Faculty of Ceyhan Veterinary Medicine, Department of Obstetrics and Gynecology, Adana, Turkey
}

Geliş Tarihi / Received: 31.03.2021, Kabul Tarihi / Accepted: 20.05.2021

\begin{abstract}
The goal of this study was to investigate pathogen types found in milk samples from cows with clinical mastitis, as well as the sensitivity of isolated bacteria to different antibiotics. The study was carried out on 103 milk samples collected from dairy cows with clinical mastitis. Microbiological isolation and identification were performed to identify gram negative and gram positive bacteria, Mycoplasma bovis and fungi. Then, bacteria isolated from infected milks were subjected to antibiogram, using 27 antimicrobials agents. As a result, a total of 146 isolates were obtained from 103 milk samples. The predominant pathogen isolates recovered were fungi (21.9\%), Escherichia coli (19.9\%) and Staphylococcus aureus (13.7\%), followed by Mycoplasma bovis (8.2\%) and Streptococcus uberis (6.8\%). The mixed predominant pathogen was fungi, (75\%) the majority of which mixed with gram positive bacteria. Ampicillin, Imipenem, Chloramphenicol and Streptomycin were the least effective antimicrobial agents, while the most effective agents were Florfenicol, followed by Amikacin and Kanamycin / Cefalexin. In conclusion, the types of microorganisms that cause mastitis and the antibiogram results of the bacteria isolated varied. Above all, fungal mastitis is a severe problem that should always be considered prior to starting antibiotic treatment.
\end{abstract}

Keywords: Antibiogram, clinical mastitis, cow, pathogen isolation

\section{Türkiye, Adana bölgesindeki klinik mastitisli sütçü ineklerde patojen izolasyonu ve antibiyogram}

\begin{abstract}
Özet: Bu çalışmanın amacı, klinik mastitisli ineklerden alınan süt örneklerinde bulunan patojen türlerini ve izole edilen bakterilerin farklı antibiyotiklere duyarlıığını araştırmaktı. Çalışma klinik mastitisli sütçü ineklerden toplanan 103 süt numunesi üzerinde gerçekleştirildi. Gram negatif ve gram pozitif bakterileri, Mycoplasma bovis ve mantarları belirlemek için mikrobiyolojik izolasyon ve tanımlama yapıldı. Ardından, enfekte sütlerden izole edilen bakteriler, 27 antimikrobiyal ajan kullanılarak antibiyograma tabi tutuldu. Çalışma sonunda, 103 süt örneğinden toplam 146 izolat elde edildi. Elde edilen dominant patojen izolatları mantarlar (\%21.9), Escherichia coli (\%19.9) ve Staphylococcus aureus (\%13.7), ardından Mycoplasma bovis (\%8.2) ve Streptococcus uberis (\%6.8) idi. Miks seyreden dominant patojen mantarlardı ve onların çoğu gram pozitif bakterilerle (\%75) miks seyretti. En etkili ajanlar sırasıyla Florfenicol, Amikacin ve Kanamycin / Cefalexin iken en az etkili antibiyotikler Ampisilin, İmipenem, Chloramphenicol ve Streptomycin oldu. Sonuç olarak, mastitise neden olan mikroorganizma türleri ve izole edilen bakterilerin antibiyogram sonuçları farklılık göstermiştir. En önemlisi, mantar kaynaklı mastitis antibiyotik tedavisine başlamadan önce her zaman dikkate alınması gereken ciddi bir sorundur.
\end{abstract}

Anahtar kelimeler: Antibiyogram, inek, klinik mastitis, patojen izolasyonu

\section{Introduction}

Mastitis, which is the inflammation of the mammary gland against infectious and non-infectious factors (Bradley 2002), is known as a multifactorial problem of dairy cows that affects milk quality and quantity (Guimarães et al. 2017; He et al. 2020). Moreover, mastitis is the most common and the most costly production disease in the dairy herds (Abebe et al. 2016; Dalanezi et al. 2020) and it is an account for $38 \%$ of total economic losses caused by production diseases (Bradley 2002). Economic losses caused by mastitis are related to the decrease in milk production, treatment and labour cost, milk disposal, decrease in the sale price of milk and the culling of animals (Demir et al. 2012; Guimarães et al. 2017; Ayvazoğlu and Eşki 2019). As a result of all these, mastitis causes an about the annual loss of $\$ 159$ per cow (Dalanezi et al. 2020). Mastitis occurs in clinical and subclinical forms and their average incidence was reported as $14.2 \%$ and $30 \%$, respectively (Sundrum 2015). Furthermore, it has a serious zoonotic risk due to the presence of bacteria 
and their toxins in milk (Abebe et al. 2016). As understood, mastitis is a global problem that must be tackled effectively due to its high incidence and prevalence (Sundrum 2015; Guimarães et al. 2017)

Mastitis has various etiologies (Bradley 2002; Dalanezi et al.2020) and is most commonly caused by bacteria (Dalanezi et al. 2020). Epidemiologically, its the etiology has been categorized as environmental (Coliform) and contagious pathogens (Smith and Hogan 1993; Abebe et al. 2016). The major reservoir of contagious mastitis pathogens is cows, they are spread among animals (Fox and Gay 1993), and tend to cause chronic subclinical infections after exacerbation of clinical events (Abebe et al. 2016). Fox and Gay (1993) reported that main contagious mastitis agents suitable for this definition include Staphylococcus aureus (S. aureus), Streptococcus agalactiae (S. agalactiae), Corynebacterium bovis, Streptococcus dysgalactiae (S. dysgalactiae) and Mycoplasma spp. The main reservoir of coliform mastitis agents is the environment (Abebe et al. 2016). Approximately $90 \%$ of mastitis caused by them are clinical form. The major environmental pathogens are Escherichia coli (E. coli), Klebsiella spp., Streptococcus uberis (S. uberis), S. dysgalactiae (included in both environmental and contagious mastitis agent), Pseudomonas, Serratia and Proteus (Smith and Hogan 1993). On the other hand, it is known that viruses, fungi and algae are among the important infectious agents that cause mastitis (Dalanezi at al. 2020), and fungal mastitis (mycotic mastitis) have become an increasing problem in recent years (Jasm and Yassein 2020). The commonly encountered causes of mycotic mastitis are Candida spp., Trichosporon spp., Cryptococcus spp., Saccharomyces spp., Aspergillus spp. (Dubie et al. 2015). Because use of antibiotics may also stimulate the multiplication of fungi, increases in fungal mastitis cases may be associated with antibiotic treatment (Wawron et al. 2010), so misdiagnosed fungal mastitis can be more exacerbated. Considering the differences in pathogen types, it is understood that the fight against mastitis is a difficult and complex situation (Taponen et al. 2017; Rahman et al. 2018). Moreover, the antimicrobial resistance of bacterial agents makes the fight against mastitis more critical (Pitkala et al. 2004; Rajala-Schultz et al. 2004; Tenhagen et al. 2006; Etifu and Tilahun 2019). Consequently, agent isolation and antibiogram test have become indispensable for a successful treatment and struggle.

Antibiotic treatments were reported to be often unsuccessful in mastitis cases in the Adana region. On this situation, we hypothesized that fungal mastitis or antibiotic resistance would be common. This study was planned considering that it would be of economic importance. The aim of the present study was to investigate the pathogen types in milk samples of cows with clinical mastitis and the sensitivity of the isolated bacteria to various antibacterial drugs, in Adana region, Turkey.

\section{Materials and Methods}

\section{Animal and management}

This study was approved by the Local Ethics Committee of Ceyhan Veterinary Faculty, Cukurova University, Adana, Turkey (approval number 8/1 and 23.09.2020). The presented study was carried out on 103 milk samples collected from dairy cows with clinical mastitis in around 40 medium-scale commercial farms, Adana region, Turkey. The dairy cows had a similar lactation period, milk yield, age, parity, milking system and body condition score, and they were managed in free-stall barns under the same conditions, had free access to water. And cows did not receive any treatment before the study.

\section{Udder examination and milk sample collection}

Palpation and inspection methods were performed to examine typical signs of clinical mastitis by a veterinarian. The examination included abnormal milk, quarter asymmetry, blindness and inflammation such as redness, hotness, swelling and painful sensation. Milk samples $(20-25 \mathrm{ml})$ were collected from individual quarters with clinical mastitis to sterile falcon tubes under asepsis and antisepsis conditions. Briefly, milk sampling procedure was performed according to Laboratory Handbook on Bovine Mastitis of the National Mastitis Council (Hogan et al. 1999). After the milk samples were collected, they were immediately transported to the laboratory under the cold chain $\left(4^{\circ} \mathrm{C}\right)$.

\section{California mastitis test (CMT)}

California mastitis test (CMT) was performed for confirmation of the examination applied by inspection and palpation. The test process and the interpretation of CMT results were made according to the Baştan et al. (2008)'s instructions.

\section{Microbiological examination}

Microbiological identification and isolation were performed according to National Mastitis Council's instructions (Hogan et al. 1999) to identify gram-negative (Sphingomonas paucimobilis ( $S$. paucimobilis), E. coli, Klebsiella, Enterobacter 
aerogenes, Serratia marcescens, Pseudomonas aeruginosa ( $p$. aeruginosa), Pasteurella multocida and Pasteurella haemolytica), gram-positive bacteria (S. aureus, Staphylococcus simulans (S. simulans), Dermacoccus nishinomiyaensis (D. nishinomiyaensis), Staphylococcus chromogenes (S. chromogenes), Micrococcus luteus (M. luteus), Bacillus sublitis (B. sublitis), Staphylococcus epidermidis (S. epidermidis), S. agalactiae, Staphylococcus vitulinus (S. vitulinus), S. dysgalactiae, S. uberis, Streptococcus pyogenes, Streptococcus pneumoniae, Enterococcus cecorum (E. cecorum), Actinomyces pyogenes, Kocuria rosea ( $K$. rosea), Kytococcus sedenterius ( $K$. sedenterius) and Bacillus cereus), Mycoplasma bovis (M. bovis) and fungi. The procedures performed are summarized below as bacterioscopy and culture and biochemical identification headings.

\section{Bacterioscopy}

The milk samples collected from infected quarters were centrifuged and preparations were prepared from the sedimentation. Then, they were stained with gram staining methods for bacterioscopy examination.

\section{Culture and Biochemical Identification}

The milk samples were individually inoculated into blood agar (Oxoid, CM0055), MacConkey agar (Oxoid, CM0007) and Sabouraud Dextrose agar (Merck, 105438) using a quadrant streaking method, and they were incubated at $37^{\circ} \mathrm{C}$ for $24-48$ h. While blood agar and MacConkey agar were used for bacteriological isolation, Sabouraud Dextrose agar was used for fungal isolation. Morphologic characteristics of isolated microorganisms were observed on these primary cultures. And Gram staining was applied to define the gram reaction and shape of the cultures. Then, further biochemical tests, catalase, coagulase and oxidase tests were performed for more specific identification. Catalase test (Hydrogen peroxide solution, Catalog number: 88597, Millipore, Darmstadt, Germany) was performed using 3\% Hydrogen peroxide $\left(\mathrm{H}_{2} \mathrm{O}_{2}\right)$ and was used to identify catalase negative and catalase positive microorganism. Coagulase test (Coagulase Plasma Lyophilized. Rabbit plasma w / EDTA, Catalog number: R21052, Thermo Fisher Scientific, MA, USA) was applied to differentiate Staphylococcus species. And oxidase test (BACTIDENT ${ }^{\mathrm{TM}}$ Rapid Testing Reagents, Oxidase; Catalog number: 1.00181.0002, Merck, Darmstadt, Germany) was used to differentiate microorganisms such as Enterobacteriaceae, Pseudomonas, Vibrio, Aeromonas, Neisseria, Alcaligenes from others.

\section{PCR method for Mycoplasma bovis identification}

M. bovis from the milk samples was identified using a method, Real Time Polymerase Chain Reaction $(\mathrm{PCR})$, based on DNA extraction. Commercial Standard Real-Time PCR Detection Kit for M. bovis (Primer Design- GENESIG) was used to determine M. bovis in DNA samples by Real Time PCR method. The protocol was implemented according to the company's instructions.

\section{Antibiogram}

Bacteria isolated from infected milks were subjected to in vitro antibiotic sensitivity testing, using 27 antimicrobials agents by disc diffusion method (Bauer 1966). All antimicrobials used were Ampicillin, Nitrofrontain, Imipenem, Gentamycin, Gamithromycin, Cefquinome, Penicillin, Kanamycin, Amoxicillin / Clavulanic acid, Enrofloxacin, Neomycin / Bacitracin/ Tetracycline, Chloramphenicol, Kanamycin / Cefalexin, Sulfamethoxazole / Trimethoprim, Ceftriaxone, Cefotaxime, Amoxycicilin, Amikacin, Florfenicol, Streptomycin, Enrofloxacin, Vancomycin, Tetrasiklin, Cefapirin, Rifampin, Azitromycin and Polymyxin B. Inoculum was prepared from primary culture. Petri dishes (Lamtek) were inoculated with the help of a sterile swab. Finally, the antimicrobial discs (Oxoid, Mastdiscs) were placed into petri dishes under sterile conditions and were incubated at $37^{\circ} \mathrm{C}$ for 24 hours. The antimicrobial sensitivity of bacteria was examined on the basis of zone diameter. The results were interpreted according to the manufacturer's standard chart and recorded as sensitive or resistant. Mycoplasma was not included in antibiogram tests.

\section{Results}

A total of 146 microorganisms isolates were obtained from 103 milk samples collected from 103 cows with clinical mastitis. Out of 103 samples, 72 samples $(69.9 \%)$ yielded pure cultures of which 12 were $M$. bovis, 8 were fungi, 28 were gram negative and 24 were gram positive organisms, and the remaining 31 (30.1\%) yielded mixed cultures. Of the 146 isolates, 12 (8.2\%) were M. bovis, 32 (21.9\%) were fungi, 41 (28.0\%) were gram negative and remaining $61(41.7 \%)$ were gram positive. The predominant pathogen isolates recovered were fungi, $E$. coli and S. aureus followed by $M$. bovis and S. uberis. However, other microorganisms were minimally detected. Mixed infections caused by two or more microorganisms were detected in milk culture. The mixed predominant pathogen was fungi, $(75 \%)$ the majority of which mixed with gram positive bacteria. The results of isolation are detailed in Table 1. 
Table 1. Frequency of isolation and microorganism species isolated from milk samples with clinical mastitis.

\begin{tabular}{|c|c|c|c|c|}
\hline Microorganism species & Gram (- / +) & No. of Isolates & $\%$ of 146 Isolates & No. of Mix \\
\hline M. bovis & & 12 & 8.2 & 0 \\
\hline Fungi & & 32 & 21.9 & 24 \\
\hline E. coli & - & 29 & 19.9 & 7 \\
\hline S. paucimobilis & - & 4 & 2.7 & 2 \\
\hline Klebsiella spp. & - & 4 & 2.7 & 2 \\
\hline P. aeruginosa & - & 2 & 1.4 & 0 \\
\hline Other gram (-) bacteria & - & 2 & 1.4 & 2 \\
\hline S. aureus & + & 20 & 13.7 & 9 \\
\hline S. simulans & + & 5 & 3.4 & 4 \\
\hline S. chromogenes & + & 3 & 2 & 0 \\
\hline S. uberis & + & 10 & 6.8 & 4 \\
\hline M. luteus & + & 1 & 0.7 & 1 \\
\hline B. sublitis & + & 5 & 3.4 & 5 \\
\hline S. epidermidis & + & 3 & 2 & 2 \\
\hline S. agalactiae & + & 1 & 0.7 & 1 \\
\hline E. cecorum & + & 1 & 0.7 & 1 \\
\hline S. vitulinus & + & 1 & 0.7 & 0 \\
\hline K. rosea & + & 1 & 0.7 & 1 \\
\hline D. nishinomiyaensis & + & 3 & 2 & 3 \\
\hline K. sedenterius & + & 1 & 0.7 & 1 \\
\hline Other gram (+) bacteria & + & 6 & 4.1 & 5 \\
\hline Total & & 146 & 100 & 74 \\
\hline
\end{tabular}

Table 2. Results of in vitro antibiogram examinations on bacteria isolated from 103 milk samples with clinical mastitis

\begin{tabular}{|c|c|c|c|c|c|c|c|c|c|c|c|c|c|c|c|c|c|c|c|c|}
\hline \multirow[b]{2}{*}{$\begin{array}{l}\text { Bacterial species } \\
\text { (No. of isolates) }\end{array}$} & \multicolumn{20}{|c|}{ In vitro antibiogram sensitivity test results in percentage } \\
\hline & 屴 & $\mathbb{\circlearrowleft}$ & 嵌 & a & $\underline{Y}$ & $\sum_{<}^{U}$ & 号 & $\frac{\mathbf{m}}{\mathbf{z}}$ & 운 & 㲌 & $\stackrel{x}{n}$ & 웁 & $\stackrel{x}{\mathfrak{u}}$ & $\sum_{<}^{+1}$ & 产 & 岀 & $n$ & 号 & $>$ & $\vdash$ \\
\hline E. coli (29) & 3.4 & 31 & 10.3 & 0 & 0 & 0 & 0 & 0 & 0 & 37.9 & 6.8 & 3.4 & 6.8 & 6.8 & 10.3 & 20.6 & 0 & 3.4 & 0 & 3.4 \\
\hline S. paucimobilis (4) & 0 & 50 & 25 & 0 & 0 & 0 & 25 & 25 & 0 & 0 & 0 & 0 & 25 & 0 & 0 & 50 & 0 & 25 & 0 & 25 \\
\hline Klebsiella spp (4) & 0 & 25 & 75 & 25 & 25 & 25 & 0 & 25 & 0 & 25 & 0 & 0 & 0 & 0 & 75 & 50 & 0 & 0 & 0 & 0 \\
\hline P. aeruginosa (2) & 0 & 0 & 50 & 0 & 0 & 0 & 50 & 0 & 0 & 0 & 50 & 0 & 0 & 0 & 50 & 0 & 0 & 50 & 0 & 0 \\
\hline Other gram (-) (2) & 0 & 0 & 0 & 0 & 0 & 0 & 0 & 0 & 0 & 50 & 0 & 0 & 0 & 0 & 100 & 50 & 0 & 0 & 0 & 0 \\
\hline S. aureus (20) & 0 & 25 & 25 & 5 & 0 & 0 & 5 & 0 & 0 & 30 & 5 & 0 & 0 & 5 & 40 & 40 & 0 & 20 & 5 & 5 \\
\hline S. simulans (5) & 20 & 0 & 0 & 0 & 0 & 0 & 60 & 0 & 0 & 0 & 0 & 20 & 0 & 0 & 20 & 40 & 0 & 0 & 20 & 0 \\
\hline S. chromogenes (3) & 0 & 0 & 0 & 0 & 0 & 0 & 0 & 0 & 0 & 0 & 0 & 0 & 0 & 0 & 0 & 0 & 0 & 0 & 0 & 0 \\
\hline S. uberis (10) & 0 & 20 & 20 & 0 & 10 & 20 & 20 & 30 & 0 & 60 & 0 & 0 & 0 & 10 & 80 & 50 & 0 & 0 & 0 & 0 \\
\hline M. luteus (1) & 0 & 0 & 100 & 0 & 0 & 0 & 0 & 0 & 0 & 0 & 0 & 0 & 0 & 0 & 0 & 100 & 0 & 100 & 0 & 0 \\
\hline B. sublitis (5) & 0 & 80 & 40 & 20 & 0 & 0 & 0 & 0 & 0 & 40 & 0 & 0 & 0 & 0 & 20 & 40 & 0 & 20 & 0 & 40 \\
\hline S. epidermidis (3) & 0 & 66.6 & 0 & 0 & 0 & 0 & 0 & 0 & 33.3 & 33.3 & 0 & 0 & 66.6 & 0 & 33.3 & 66.6 & 0 & 33.3 & 0 & 0 \\
\hline S. vitulinus (1) & 0 & 0 & 0 & 0 & 0 & 0 & 0 & 0 & 0 & 0 & 0 & 0 & 0 & 0 & 100 & 100 & 100 & 0 & 0 & 0 \\
\hline K. rosea $(1)$ & 0 & 100 & 0 & 0 & 0 & 0 & 0 & 0 & 0 & 100 & 0 & 0 & 0 & 0 & 100 & 0 & 0 & 0 & 0 & 0 \\
\hline D. nishinomiyaensis (3) & 0 & 33.3 & 0 & 0 & 0 & 0 & 0 & 0 & 0 & 33.3 & 0 & 0 & 0 & 0 & 33.3 & 0 & 0 & 0 & 0 & 0 \\
\hline K. sedenterius (1) & 0 & 100 & 0 & 0 & 0 & 0 & 0 & 0 & 0 & 100 & 0 & 0 & 0 & 0 & 100 & 0 & 0 & 0 & 0 & 0 \\
\hline Other gram (+) (6) & 0 & 0 & 16.6 & 0 & 0 & 16.6 & 0 & 0 & 0 & 33.3 & 16.6 & 0 & 0 & 0 & 33.3 & 50 & 0 & 0 & 0 & 0 \\
\hline Total (102) & 1.9 & 27.4 & 18.6 & 2.9 & 1.9 & 3.9 & 6.2 & 4.9 & 0.9 & 32.3 & 4.9 & 1.9 & 4.9 & 3.9 & 33.3 & 34.3 & 0.9 & 8.8 & 1.9 & 3.9 \\
\hline
\end{tabular}

NTF: Nitrofrontain, GA: Gamithromycin, CEA: Cefquinome, P: Penicillin, K: Kanamycin, AMC: Amoxicillin / Clavulanic acid, ENR: Enrofloxacin, NBT: Neomycin / Bacitracin / Tetracycline, CRO: Chloramphenicol, KCFX: Kanamycin / Cefalexin, STX: Sulfamethoxazole / Trimethoprim, CRO: Ceftriaxone, CTX: Cefotaxime, AML: Amoxycicilin, AK: Amikacin, FFC: Florfenicol, S: Streptomycin, ENR: Enrofloxacin, $\mathrm{V}$ : Vancomycin, T: Tetrasiklin 
The antibiogram conducted on the bacteria isolated from infected milk samples showed different results, which may vary from agent to agent. Cefapirin, Rifampin, Azitromycin and Polymyxin B had no effect any bacterial isolate. Ampicillin (5\%), Imipenem (5\%), Gentamycin (10\%) had an effect only on S. aures. And considering all cases, Ampicillin, Imipenem, Chloramphenicol and Streptomycin were the least effective antimicrobial agents, while the most effective antibiotic was Florfenicol, followed by Amikacin and Kanamycin / Cefalexin. On the other hand, $48.2 \%$ of E. coli, $25 \%$ of S. paucimobilis, $20 \%$ of S. aureus, $40 \%$ of S. simulans, $100 \%$ of S. chromogenes, $10 \%$ of S. uberis, $33.3 \%$ of other gram (+) bacteria, $100 \%$ of S. agalactiae and $100 \%$ of $E$. cecorum showed resistance to all antimicrobial agents. The effective antibiogram results are given in Table 2 .

\section{Discussion and Conclusion}

In the present study, firstly the types of microorganisms that cause clinical mastitis were determined. Then, the sensitivity of isolated bacterial pathogens to 27 different antibacterial agents was investigated. Among the microorganisms isolated in this study, fungi, E. Coli and S. aureus were determined as the major cause of mastitis, but the obtained result showed some differences compared to the previous report (Green et al. 2002; Baştan et al. 2008; Rahman et al. 2018).

It has been reported that fungi are usually agents in bovine mastitis and are commonly considered to be an environmental mastitis agent due to poor hygiene (Krukowski et al. 2001). There are different types of fungi that cause mycotic mastitis (Du et al. 2018). However, its most common cause was found the genus Candida (Zaragoza et al. 2011; Eldesouky et al. 2016; Du et al. 2018). They may be also associated with clinical mastitis (Jasm and Yassein 2020). In the present study, because the main aim was to investigate the importance of fungi in mastitis cases, no species distinction was performed. It has been reported that the prevalence of mycotic mastitis has considerably increased in recent years (Zhou et al. 2013) and the rates of fungi isolated from milk with mastitis differed significantly by country. And this rate was noted as $12.1 \%$ in Turkey (Jasm and Yassein 2020). However, it was found to be higher (31.06\%) in our study. We considered that it may be due to Adana's subtropical climate (Krukowski and Saba 2003). Antibiotics are administered more frequently in routine mastitis treatment and antifungal treatment is not given importance (Pachauri et al. 2013). However, the presence of fungi in mastitis cases reveals the importance of pathogen isolation for treatment and control. Moreover, the differences in bacterial species isolated and their antibiotic resistance make the situation even more critical. The results demonstrated that $48.27 \%$ of $E$. coli isolated developed resistance to all antimicrobial agents used in this study. And the most effective antimicrobial agent against $E$. coli was Kanamycin / Cefalexin (37.93\%). Another study showed that $E$. coli has a sensitivity of $94.59 \%$ against Chloramphenicol in buffaloes (Charaya et al. 2014). Mohanty et al. (2013) reported that $E$. coli were the most sensitive toward Levofloxacin (96.66\%) and Chloramphenicol (90\%). Similarly, other studies showed differences in antimicrobial agents to which E. coli was sensitive (Tenhagen et al. 2006; Bhat et al. 2017; Taponen et al. 2017). It also is known that the treatment process of cases of $E$. coli is easier than cases of $S$. aureus, another major pathogen (Luoreng et al. 2018). And its rate and spread in the herd is closely related to management (Rainard et al. 2018). In a previous study, all staphylococcal species including $S$. aureus were determined at a rate of $20.4 \%$ (Twomey et al. 2000), which is similar to the ratio of our study. Antibiotic treatment is mostly ineffective for mastitis caused by $S$. aureus (Luoreng et al. 2018). In the present study, results of antibiogram test for $S$. aureus showed that Amikacin (40\%) and Florfenicol (40\%) to be the most effective of all antibiotics. Charaya et al. (2014) also reported that Amikacin (88.57\%) the most effective antibiotic for $S$. aureus isolated in buffaloes. On the other hand, several studies declared that $S$. aureus is most sensitive to Enrofloxacin and Ciprofloxacin (Ismail 2017), Levofloxacin (88.23\%) and Enrofloxacin (88.23\%) (Mohanty et al. 2013), Gentamicin (100\%) and Erythromycin (100\%) (Tenhagen et al. 2006). It was also observed that there was a difference in the rates of isolated S. aureus in these studies. Other important pathogens isolated in the present study were M. bovis (8.2\%) and S. uberis (6.8\%). Mastitis caused by mycoplasma is not as common as mastitis caused by other bacteria (Nicholas et al. 2016). However, it generally does not respond to antibiotic therapy and highly contagious (Fujimoto et al. 2020; Liu et al. 2020). It also has been reported that mycoplasma has no cell wall (Parker et al. 2018) and to be resistant to all major classes of antimicrobial drugs. Therefore, the control of mycoplasma mastitis with antibiotic treatment is usually unsuccessful (Nicholas et al. 2016). As understood, protection and 
prevention come to the fore in the fight against this pathogen. For these reasons, we did not perform an antibiogram test against M. bovis.

It was declared that $S$. uberis is among the most important factors causing bovine mastitis (Käppeli et al. 2019), has an increasing prevalence worldwide and responsible for 14 to $26 \%$ of clinical mastitis (Phuektes et al. 2001). On the other hand, Käppeli et al. (2019) reported that clinical mastitis cases caused by $S$. uberis have decreased with preventive control studies. Antibiogram results of the study conducted by Phuektes et al. (2001) showed that all isolates of $S$. uberis sensitive towards Vancomycin and Cephalexin. Other studies revealed that the most effective antimicrobial agents against to Streptococcus species isolated were Chloramphenicol and Tetracycline (100\%) (Kurjogi and Kaliwal 2011), Levofloxacin, Enrofloxacin and Ciprofloxacin (Mohanty et al. 2013) However, no similar results were observed by the current study, we found that $S$. uberis the most sensitive to (80\%) Amikacin, followed by Kanamycin / Cefalexin (60\%).

Antimicrobial agents effective against minor pathogens isolated in our study and their effectiveness rates showed different distributions and results. Furthermore, some antibiotics had a higher success rate on them compared to major pathogenes. We interpreted this as that these bacteria develop less antibiotic resistance since they are not the common cause of mastitis. We also thought that the differences in isolated microorganism and antibiotic resistance vary according to the regions where the study was conducted, management conditions, hygiene and the antibiotics preferred in previous treatments.

In conclusion, the types of microorganisms that cause mastitis and the antibiogram results of the bacteria isolated varied, and the predominant pathogens were fungi, E. coli and S. aureus. Fungal mastitis is serious problem, should always be considered before routine antibiotic therapy and emphasis should be given on antifungal therapy. Considering all bacterial cases, the most effective antibiotic was Florfenicol, followed by Amikacin and Kanamycin / Cefalexin, respectively. However, a one-sided treatment cannot be successful in mastitis. Therefore, determine the pathogens that cause mastitis and the selection of the appropriate treatment are very important in the prevention, control and treatment process.

Ethic statement: Ethical approval This article has not been published previously and is not under consideration for publication elsewhere. The publication of this article is approved by all authors and explicitly by the responsible authorities where the work was carried out. This study was approved by the Local Ethics Committee of Ceyhan Veterinary Faculty, Cukurova University, Adana, Turkey (approval number 8/1 and 23.09.2020).

Conflict of interest: The authors declare that they have no conflict of interest.

\section{References}

Abebe R, Hatiya H, Abera M, Megersa B, Asmare K. (2016) Bovine mastitis: prevalence, risk factors and isolation of Staphylococcus aureus in dairy herds at Hawassa milk shed, South Ethiopia. BMC Vet Res, 12, 1-11.

Ayvazoğlu Demir P, Eşki F. (2019) Estimate by Quantitative Methods of the Effect on Some Milk Yield Traits with CMT Score of Subclinic Mastitis in Cows: Pilot Study. Van Vet $J$, 30, 177-182.

Baştan A, Kaçar C, Acar DB, Şahin M, Cengiz M. (2008) Investigation of the incidence and diagnosis of subclinical mastitis in early lactation period cows. Turkish J Vet Anim Sci, 32, 119-121.

Bauer AW. (1966) Antibiotic susceptibility testing by a standardized single disc method. Am J Clin, 45, 149-158.

Bhat AM, Soodan JS, Singh R, Dhobi IA, Hussain T, Dar MY, Mir M. (2017) Incidence of bovine clinical mastitis in Jammu region and antibiogram of isolated pathogens. Vet World, 10, 984989.

Bradley AJ. (2002) Bovine mastitis: an evolving disease. Vet J, 164, 116-128.

Charaya G, Sharma A, Kumar A, Singh M, Goel P. (2014) Pathogens isolated from clinical mastitis in Murrah buffaloes and their antibiogram. Vet World, 7, 980-985.

Dalanezi FM, Joaquim SF, Guimarães FF, Guerra ST, Lopes BC, Schmidt EMS, Cerri RLA, Langoni H. (2020) Influence of pathogens causing clinical mastitis on reproductive variables of dairy cows. J Dairy Sci, 103, 3648-3655.

Demir P, Derbentli Ö, Sakarya E. (2012) Measurement the Efficiency of Dairies in the Kars Province with Data Envelopment Analysis. Kafkas Univ Vet Fak Derg, 18, 169-17622.

Du J, Wang X, Luo H, Wang Y, Liu X, Zhou X. (2018) Epidemiological investigation of non-albicans Candida species recovered from mycotic mastitis of cows in Yinchuan, Ningxia of China. BMC Vet Res, 14, 1-9.

Dubie T, Sisay T, Gebru M, Muktar Y. (2015) An insight review on the role of fungi in mastitis of dairy animals and its economical importance. J Vet Sci Photon, 116, 440-445.

Eldesouky I, Mohamed N, Khalaf D, Salama A, Elsify A, Ombarak R, Elballal S, Effat M, Alshabrawy M. (2016) Candida mastitis in dairy cattle with molecular detection of Candida albicans. Kafkas Univ Vet Fak Derg, 22, 461-464.

Etifu M, Tilahun M. (2019) Prevalence of bovine mastitis, risk factors, isolation and anti-bio gram of major pathogens in Mid Rift valley, Ethiopia. IJLP, 10, 14-23.

Fox LK, Gay JM. (1993) Contagious mastitis. Vet Clin North Am Food Anim Pract, 9, 475-487.

Fujimoto $\mathrm{Y}$, Ito H, Higuchi H, Ohno H, Makita K. (2020) A casecontrol study of herd-and cow-level risk factors associated with an outbreak of Mycoplasma mastitis in Nemuro, Japan. Prev Vet Med, 177, 1-9. 
Green MJ, Green LE, Medley GF, Schukken YH, Bradley AJ. (2002) Influence of dry period bacterial intramammary infection on clinical mastitis in dairy cows. J Dairy Sci, 85, 2589-2599.

Guimarães JLB, Brito MAVP, Lange CC, Silva MR, Ribeiro JB, Mendonça LC, Mendonça JFM, Souza GN. (2017) Estimate of the economic impact of mastitis: A case study in a Holstein dairy herd under tropical conditions. Prev Vet Med, 142, 4650.

He W, Ma S, Lei L, He J, Li X, Tao J, Wang X, Song S, Wang $Y$, Wang Y, Shen J, Cai C, Wu C. (2020) Prevalence, etiology, and economic impact of clinical mastitis on large dairy farms in China. Vet Microbiol, 242, 1-7.

Hogan JS, Gonzalez RN, Harmon RJ, Nickerson SC, Oliver SP, Pankey JW, Smith KL, Hogan J, Armas-Portela R, Harmon R, Nickerson SC, Oliver S, Pankey J. (1999) Laboratory handbook on bovine mastitis. National Mastitis Council, Madison, Wisconsin.

Ismail ZB. (2017) Molecular characteristics, antibiogram and prevalence of multi-drug resistant Staphylococcus aureus (MDRSA) isolated from milk obtained from culled dairy cows and from cows with acute clinical mastitis. Asian Pac J Trop Biomed, 7, 694-697.

Jasm Mohammed S, Yassein SN. (2020) Characterization of some virulence factors of candida albicans isolated from subclinical bovine mastitis. Plant Arch, 20, 238-242.

Käppeli N, Morach M, Zurfluh K, Corti S, Nüesch-Inderbinen M, Stephan R. (2019) Sequence types and antimicrobial resistance profiles of Streptococcus uberis isolated from bovine mastitis. Front Vet Sci, 6, 1-7.

Krukowski H, Saba L. (2003) Bovine mycotic mastitis. Folia Vet 47, 3-7.

Krukowski H, Tietze M, Majewski T, Różański P. (2001) Survey of yeast mastitis in dairy herds of small-type farms in the Lublin region, Poland. Mycopathologia, 150, 5-7.

Kurjogi MM, Kaliwal BB. (2011) Prevalence and antimicrobial susceptibility of bacteria isolated from bovine mastitis. Adv Appl Sci Res, 2, 229-235.

Liu Y, Xu S, Li M, Zhou, M, Huo W, Gao J, Liu G, Kastelic JP, Han B. (2020) Molecular characteristics and antibiotic susceptibility profiles of Mycoplasma bovis associated with mastitis on dairy farms in China. Prev Vet Med, 182, 1-9.

Luoreng ZM, Wan X.P, Mei CG, Zan LS. (2018) Comparison of microRNA profiles between bovine mammary glands infected with Staphylococcus aureus and Escherichia coli. Int J Biol Sci, 14, 87-99.

Mohanty NN, Das P, Pany SS, Sarangi LN, Ranabijuli S, Panda HK. (2013) Isolation and antibiogram of Staphylococcus, Streptococcus and Escherichia coli isolates from clinical and subclinical cases of bovine mastitis. Vet World, 6, 739-743.

Nicholas RA, Fox LK, Lysnyansky I. (2016) Mycoplasma mastitis in cattle: To cull or not to cull. Vet J, 216, 142-147.

Pachauri S, Varshney P, Dash SK, Gupta MK. (2013) Involvement of fungal species in bovine mastitis in and around Mathura, India. Vet World, 6, 393-395.
Parker AM, Sheehy PA, Hazelton MS, Bosward KL, House JK (2018) A review of mycoplasma diagnostics in cattle. J Vet Intern Med, 32, 1241-1252.

Phuektes P, Mansell PD, Dyson RS, Hooper ND, Dick S, Browning GF. (2001) Molecular epidemiology of Streptococcus uberis isolates from dairy cows with mastitis. J Clin Microbiol, 39, 1460-1466.

Pitkala A, Haveri M, Pyörala S, Myllys V, Honkanen-Buzalski T. (2004) Bovine mastitis in Finland 2001-prevalence, distribution of bacteria, and antimicrobial resistance. J Dairy Sci, 87, 2433-2441.

Rahman MM, Fakhruzzaman M, Rahman M, Khaton R, Iqbal SM, Sharmin S, Islam MH. (2018) Isolation, identification and antibiogram study of Escherichia coli from the cases of mastitis. $B L J, 1,1-6$.

Rainard P, Foucras G, Fitzgeral J.R, Watts JL, Koop G, Middleton JR. (2018) Knowledge gaps and research priorities in Staphylococcus aureus mastitis control. Transbound Emerg Dis, 65, 149-165.

Rajala-Schultz PJ, Smith KL, Hogan JS, Love BC. (2004) Antimicrobial susceptibility of mastitis pathogens from first lactation and older cows. Vet Microbiol, 102, 33-42.

Smith KL, Hogan JS. (1993) Environmental mastitis. Vet Clin North Am Food Anim Pract, 9, 489-498.

Sundrum A. (2015) Metabolic disorders in the transition period indicate that the dairy cows' ability to adapt is overstressed. Animals, 5, 978-1020.

Taponen S, Liski E, Heikkilä AM, Pyörälä S. (2017) Factors associated with intramammary infection in dairy cows caused by coagulase-negative staphylococci, Staphylococcus aureus, Streptococcus uberis, Streptococcus dysgalactiae, Corynebacterium bovis, or Escherichia coli. J Dairy Sci, 100, 493-503.

Tenhagen BA, Köster G, Wallmann J, Heuwieser W. (2006) Prevalence of mastitis pathogens and their resistance against antimicrobial agents in dairy cows in Brandenburg, Germany. J Dairy Sci, 89, 2542-2551.

Twomey DP, Wheelock Al, Flynn J, Meaney WJ, Hill C, Ross RP. (2000) Protection against Staphylococcus aureus mastitis in dairy cows using a bismuth-based teat seal containing the bacteriocin, lacticin. J Dairy Sci, 83, 1981-1988.

Wawron W, Bochniarz M, Piech T. (2010) Yeast mastitis in dairy cows in the middle-eastern part of Poland. Bull Vet Inst Pulawy, 5, 201-204.

Zaragoza CS, Olivares RAC, Watty AD, Moctezuma AL, Tanaca LV. (2011) Yeasts isolation from bovine mammary glands under different mastitis status in the Mexican High Plateu. Rev Iberoam Micol, 28, 79-82.

Zhou Y, Ren Y, Fan C, Shao H, Zhang Z, Mao W, Wei C, Ni H, Zhu Z, Hou X, Piao F, Cui Y. (2013) Survey of mycotic mastitis in dairy cows from Heilongjiang Province, China. Trop Anim Health Prod, 45, 1709-1714. 